\title{
DPC4 gene mutation in colitis associated neoplasia
}

\author{
A T M S Hoque, S A Hahn, M Schutte, S E Kern
}

\begin{abstract}
Background-Colitis associated dysplasia and cancer often have deletions involving the long arm of chromosome 18q, suggesting the location of a tumour suppressor gene critical for their tumorigenesis. The DPC4 gene, which is genetically inactivated in pancreatic and other cancers, has recently been described.

Aim-Because DPC4 is located at $18 \mathrm{q} 21 \cdot 1$, the hypothesis that it could be a mutated tumour suppressor gene in colitis associated neoplasms was tested.

Patients-Advanced neoplastic lesions from six patients having chronic colitis were analysed for DPC4.

Methods-Individual exons of DPC4 were amplified by the polymerase chain reaction (PCR) and sequenced from genomic DNA of tissue specimens dissected by cryostat.

Results-DPC4 was found to have biallelic inactivation in one of three neoplasms shown to have allelic loss of 18q. The mutation had been acquired somatically in a plaque of high grade dysplasia. The mutation created a non-sense codon, which would cause premature termination of protein translation.

Conclusion-The DPC4 gene is a target of $18 q$ LOH events in colitis associated neoplasia.

(Gut 1997; 40: 120-122)
\end{abstract}

Keywords: $\mathrm{LOH}$, loss of heterozygosity, in vitro synthesised protein assay, in vitro synthesis.

Chronic ulcerative colitis and Crohn's disease are associated with an increased risk of colorectal neoplasia. Detailed studies to show the genetic alterations in these neoplasms identified K-ras mutations, $17 \mathrm{p}$ deletions, and p53 mutations, 5q deletions, $A P C$ mutations, and $18 \mathrm{q}$ deletions at significant rates. ${ }^{1-8}$ Thus the types of genetic alterations in these neoplasms were not distinctly different from those seen in sporadic colorectal adenomas and car- cinomas. Allelic losses of $18 \mathrm{q}$ are among the most common deletions seen in a large variety of human malignancies. ${ }^{910}$ One candidate tumour suppressor gene on chromosome $18 \mathrm{q}$ is the $D C C$ gene. However, DCC is among the largest genes known, and mutational analyses have been difficult. ${ }^{11}$ We recently identified another candidate tumour suppressor gene at $18 \mathrm{q} 21 \cdot 1, D P C 4$ (deleted in pancreatic carcinoma, locus 4). ${ }^{10}$ DPC4 4 was genetically inactivated by homozygous deletion in a third of pancreatic carcinomas. On sequencing of the coding region of DPC4, performed in tumours without homozygous deletion, intragenic mutations were identified in another $20 \%$ of the carcinomas. The finding of homozygous deletions of DPC4 in single cases of bladder and biliary cancer, as well as in two colorectal cancers, ${ }^{10}$ suggested that DPC 4 might also be involved in other types of tumour. Here we analysed the mutational status of DPC4 in colitis associated colorectal neoplasms.

\section{Methods}

PATIENTS AND SPECIMENS

Specimens were obtained from six patients with colitis associated neoplasia that were resected at The Johns Hopkins Hospital between the years 1989 and 1993. This is a well characterised set of patients, and extensive molecular genetic profiles have been published. ${ }^{12}$ Clinical information about the patients was obtained from chart review (Table I). Lesions were classified according to the 1983 Inflammatory Bowel Disease - Dysplasia Morphology Study Group Criteria (IBD-DMSGC), and diagnoses were confirmed by at least four experienced gastrointestinal pathologists. ${ }^{12}$ Patients CC-1, CC-2, CC-4, and CC- 6 had ulcerative colitis and patients CC-3 and CC-5 had Crohn's disease. All patients had pancolitis except CC-1. Patient CC-4 had high grade dysplasia and all others had carcinoma. For each patient, the most advanced lesion was examined for mutations. For CC-6, two histologically distinct areas of a carcinoma were analysed.

\section{Pathology \\ A T M S Hoque \\ S A Hahn \\ M Schutte}

Department of Oncology, The Johns Hopkins Hospital and School of Medicine, Baltimore, USA S E Kern

Correspondence to: Dr S E Kern, Department of Oncology, The Johns Hopkins Hospita Baltimore, MD 21205-2196, USA.

Accepted for publication 30 May 1996
TABLE I Clinical characteristics of patients

\begin{tabular}{|c|c|c|c|c|c|c|}
\hline Patient & $\begin{array}{l}\text { Age at } \\
\text { operation (y) }\end{array}$ & Type & Extent & $\begin{array}{l}\text { Duration } \\
\text { of colitis }(y)\end{array}$ & Site & Lesion \\
\hline $\begin{array}{l}\text { CC-1 } \\
\text { CC-2a } \\
\text { CC-3 } \\
\text { CC- } 4 \\
\text { CC-5a } \\
\text { CC-6a } \\
\text { CC-6b }\end{array}$ & $\begin{array}{l}71 \\
45 \\
40 \\
45 \\
58 \\
35\end{array}$ & $\begin{array}{l}\text { UC } \\
\text { UC } \\
\text { CD } \\
\text { UC } \\
\text { CD } \\
\text { UC }\end{array}$ & $\begin{array}{l}\text { Unknown } \\
\text { Pancolitis } \\
\text { Pancolitis } \\
\text { Pancolitis } \\
\text { Pancolitis } \\
\text { Pancolitis }\end{array}$ & $\begin{array}{l}16 \\
>10 \\
25 \\
>20 \\
37 \\
12\end{array}$ & $\begin{array}{l}\text { Rectum } \\
\text { Ascending } \\
\text { Rectum } \\
\text { Anorectum } \\
\text { Rectum } \\
\text { Ascending }\end{array}$ & $\begin{array}{l}\text { Dukes's C non-mucinous carcinoma } \\
\text { Dukes's C non-mucinous carcinoma } \\
\text { Dukes's B mucinous carcinoma } \\
\text { Plaque of high grade dysplasia. No carcinoma } \\
\text { Dukes's A mucinous carcinoma } \\
\text { Dukes's C carcinoma, non-mucinous area } \\
\text { Dukes's C carcinoma, mucinous area }\end{array}$ \\
\hline
\end{tabular}

^From a well characterised patient group described in part in previous publications. ${ }^{12} \mathrm{UC}=$ Ulcerative colitis; $\mathrm{CD}=\mathrm{Crohn}$ 's disease. 
TABLE II DPC4 primers used in the polymerase chain reaction and cycle sequencing

\begin{tabular}{|c|c|c|c|}
\hline Exon & $P C R$ primers ${ }^{\star}$ & & Sequencing primerst \\
\hline $\begin{array}{l}1 \\
2 \\
3 \\
4 \\
5 / 6\end{array}$ & $\begin{array}{l}\text { AACGTTAGCTGTTGTTTTTCAC } \\
\text { TGTATGACATGGCCAAGTTAG } \\
\text { CTGAATTGAAATGTTCATGAAC } \\
\text { TTTTGCTGGTAAAGTAGTATGC } \\
\text { CATCTTTATAGTTGTGCATTATC }\end{array}$ & $\begin{array}{l}\text { AGAGTATGTGAAGAGATGGAG } \\
\text { CAATACTCGGTTTAGCAGTC } \\
\text { GCCCCTAACCTCAAAATCTAC } \\
\text { TTTACCTATGAAAGATAGTACAG } \\
\text { CACTATTTAATGAAACAAAATCAC }\end{array}$ & $\begin{array}{l}\text { TTTCCAAAGGATCAAAATTGCTTCAG } \\
\text { TAATACTGAGTTGGTAGGATTGTGAG } \\
\text { CTCACACAAACTAATCTAGGTCAAC } \\
\text { GGAGTTTCCCCCAAGTGACTAC } \\
\text { TGAAATCATAAGATGACATCTATGAATG } \\
\text { TCCGGGATGGGGCGGCATAG } \\
\text { CTGGACTGGAAGTAGGACTG }\end{array}$ \\
\hline $\begin{array}{l}7 \\
8 \\
9 \\
10 \\
11\end{array}$ & $\begin{array}{l}\text { TGAAAGTTTTAGCATTAGACAAC } \\
\text { TGTTTTGGGTGCATTACATTTC } \\
\text { TATTAAGCATGCTATACAATCTG } \\
\text { AGGCATTGGTTTTTAATGTATG } \\
\text { CCAAAAGTGTGCAGCTTGTTG }\end{array}$ & $\begin{array}{l}\text { TGTACTCATCTGAGAAGTGAC } \\
\text { CAATTTTTTAAAGTAACTATCTGAC } \\
\text { CTTCCACCCAGATTTCAATTC } \\
\text { CTGCTCAAAGAAACTAATCAAC } \\
\text { CAGTTTCTGTCTGCTAGGAG }\end{array}$ & $\begin{array}{l}\text { CACTAAATCAATCTAAATACAGGAAATC } \\
\text { TGTGTTGTGGAGTGCAAGTGAAAG } \\
\text { TTTTGACAACAAATAGAGCTTTAAGTC } \\
\text { GAATTTCTTTATGAACTCATAG } \\
\text { TATTTTGTAGTCCACCATC }\end{array}$ \\
\hline
\end{tabular}

^For PCR, exons 5 and 6 are coamplified using a single primer pair.

†For sequencing, exon 5 requires a single sequencing primer, and is listed first. Exon 6 requires two primers due to its larger size.

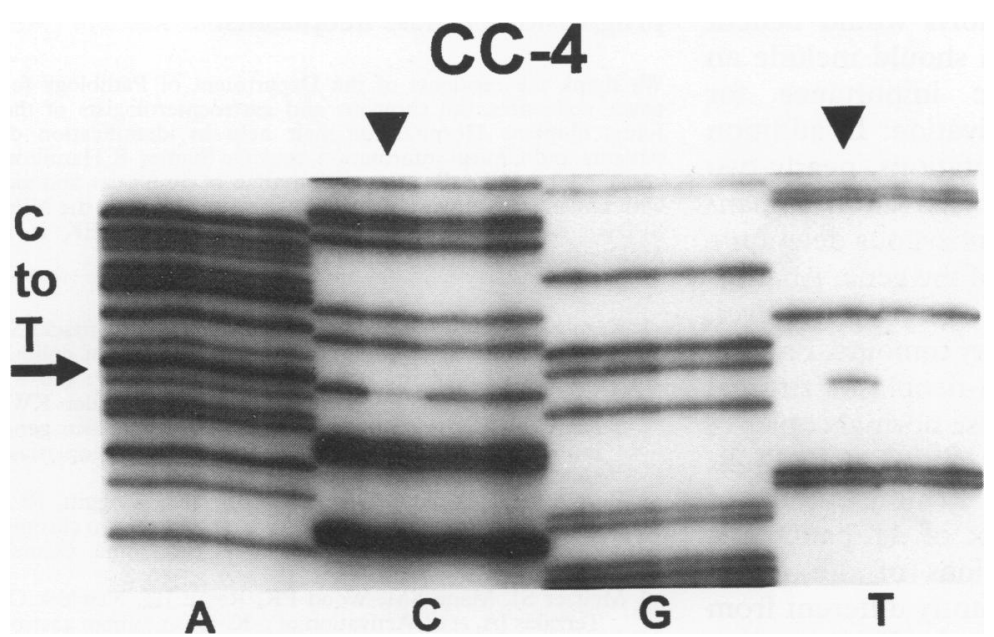

DPC4 mutation detection in a colitis associated dysplasia. There are four lanes for each nucleotide $(A, C, G$, and $T)$, representing four independent tissue samples. The high grade dysplasia in patient CC-4 (represented in the second lane for each nucleotide) has a $C$ to $T$ nucleotide substitution, producing a new band in the $T$ lane and a reduction of intensity in the $C$ lane (arrows). The residual signal in the Clane is from the non-neoplastic stromal and inflammatory cells in the tumour sample, which contain the wild type sequence. The mutation was not identified in the corresponding normal specimen of the same patient (represented in the first lane for each nucleotide).

DPC4 MUTATION DETECTION

Amplification by polymerase chain reaction (PCR) and cycle sequencing of exons 1 through 11 was performed. Primers (Table II) were derived from intronic or non-coding regions and used for PCR amplification of the 11 exons from genomic DNA of each lesion. Products from PCR were treated with exonuclease I and shrimp alkaline phosphatase, according to the manufacturer's recommendations (USB, Cleveland, OH, USA). Direct sequencing was performed by Sequitherm cycle sequencing, according to the manufacturer's recommendations (Epicentre Technologies, Madison, WI, USA) (Table II).

\section{Results}

Six colitis associated neoplasia specimens were analysed for DPC4 alterations by PCR amplification and cycle sequencing. A high grade dysplasia from patient CC-4 contained a nonsense mutation of DPC4 in exon 11 (codon 516), which changed a glutamine codon (CAG) to a stop codon (TAG). The mutation was confirmed by sequencing the product of an independently amplified PCR product and by sequencing the PCR product in the opposite direction using another primer. The site of mutation was sequenced from non-neoplastic mucosa from the same patient to establish the somatic nature of the mutation. The Figure gives an example of the sequencing results. Specimen CC-4 was one of three lesions in this study known to have allelic loss of $18 \mathrm{q}$, indicating that the DPC4 gene was biallelically inactivated in this specimen. No other alterations of DPC4 were identified among the six patients. The mutational status of DPC4 was combined with previous data to provide updated molecular genetic profiles for these lesions (Table III).

\section{Discussion}

We recently identified the candidate tumour suppressor gene DPC4. It was inactivated in nearly half of pancreatic carcinomas. The site

TABLE III DPC4 status and molecular genetic profiles of colitis associated neoplasms

\begin{tabular}{|c|c|c|c|c|c|c|c|c|c|}
\hline Sample & $K-$ ras $^{\star}$ & $A P C^{\star}$ & $\begin{array}{l}5 q \\
\text { Loss }\end{array}$ & $p 53^{a}$ & $17 p$ Loss & $D P C 4^{\star}$ & $\begin{array}{l}18 q \\
\text { Loss }\end{array}$ & $F A L \dagger$ & $R E R$ \\
\hline CC-1 & - & - & $\mathrm{LOH}$ & $282 \mathrm{R} \rightarrow \mathrm{W}$ & $\mathrm{LOH}$ & - & $\mathrm{LOH}$ & 0.43 & - \\
\hline CC-2a & $12 \mathrm{G} \rightarrow \mathrm{D}$ & - & - & $195 \mathrm{I} \rightarrow \mathrm{T}$ & $\mathrm{LOH}$ & - & - & $0 \cdot 15$ & - \\
\hline CC-3 & $12 \mathrm{G} \rightarrow \mathrm{D}$ & - & - & $179 \mathrm{H} \rightarrow \mathrm{Y}$ & LOH & - & LOH & $0 \cdot 29$ & - \\
\hline $\begin{array}{l}\text { CC-4 } \\
\text { CC-5a }\end{array}$ & $\overline{12} \mathrm{G} \rightarrow \mathrm{D}$ & $\begin{array}{l}1450 \mathrm{R} \rightarrow \text { stop } \\
1556 \mathrm{fs} \text { ins } \\
1534 \mathrm{fs} \text { del }\end{array}$ & $\overline{\mathrm{LOH}}$ & $\begin{array}{l}278 \text { fs del } \\
262 \text { splice } \\
248 \mathrm{R} \rightarrow \mathrm{Q}\end{array}$ & $\begin{array}{l}\mathrm{LOH} \\
\mathrm{LOH}\end{array}$ & $516 \mathrm{Q} \rightarrow$ stop & $\begin{array}{l}\text { LOH } \\
\text { ND }\end{array}$ & $\begin{array}{l}0 \cdot 22 \\
0 \cdot 16\end{array}$ & - \\
\hline CC-6a & - & - & - & $282 \mathrm{R} \rightarrow \mathrm{W}$ & - & - & - & 0.00 & + \\
\hline CC-6b & - & - & - & $282 \mathrm{R} \rightarrow \mathrm{W}$ & - & - & - & 0.00 & + \\
\hline
\end{tabular}

LOH=LOH found; +=multiple allelic shifts indicative of RER $^{+}$phenotype; -=no LOH, mutations, or allelic shifts detected; $\mathrm{ND}=$ not determined. ${ }^{\star} \mathrm{K}$-ras, $p 53$, and $D P C 4$ mutations are given by codon and the predicted translation product using the single letter amino acid code. fs del=frameshift deletion mutation; fs ins=frameshift insertion; splice=splice acceptor site mutation. For $A P C$, mutations were identified by a screening assay for mutations producing truncated products, and the failure to identify a mutation does not exclude the possibility of other types of mutations. For DPC4, the presence of homozygous deletions is not excluded. CC-4 had two mutations in $A P C$. CC-6a had a p53 mis-sense mutation on each allele. †FAL = fractional allelic loss. Mutations of DPC4 status from the current study is shown in a genetic context with data from previous publications. ${ }^{12}$ 
of DPC4, at $18 \mathrm{q} 21 \cdot 1$ near the DCC gene, is known to be commonly involved in loss of heterozygosity events in colitis associated neoplasms. The deletions of chromosome 18, however, often involve very large regions, and it has been difficult to identify the gene(s) which may serve as the genetic target of these events. Here, we report a DPC4 point mutation in one of three advanced colitis associated neoplasms which harboured allelic loss of 18q. This is the first gene target on $18 \mathrm{q}$ to be pinpointed by the identification of a point mutation in colitis associated dysplasia. Interestingly, the mutation was found in the non-invasive dysplastic plaque, rather than the carcinomas. Follow up efforts would benefit from a larger series, which should include an assessment of prognostic importance for lesions having $D P C 4$ inactivation. In addition to inactivation by point mutations, nearly two thirds of the DPC4 gene inactivation in pancreatic cancer occur by homozygous deletion that is, loss of both copies of the gene. Analysis for this type of genetic event is, however, technically difficult in primary tumours. Primary tumour tissue contains non-neoplastic stromal and inflammatory cells whose normal copies of the DPC4 gene would be amplified in the PCR, thus impairing a direct demonstration of homozygous gene loss. Six of 41 pancreatic tumours contained mutations of the DPC4 gene sequence, not significantly different from the results of the current study. By extension, colitis associated neoplasms might also harbour homozygous deletions of DPC4, which could not be assayed with the methods used here. The intragenic mutation identified in one of the specimens in this series, however, would now justify further dedicated studies of homozygous deletions of DPC4 in colitis associated dysplasias and cancers. For this, specialised techniques will be required, such as microdissection to isolate neoplastic cells, or the detection of "apparent retention of heterozygosity" through the use of polymorphic markers at sites of homozygous deletion in primary tumour tissues. ${ }^{12}$ The mutation reported here was a non-sense mutation in exon 11 of the DPC4 gene. Interestingly, five of six DPC4 mutations identified in pancreatic carcinoma also abolished exon 11 of DPC4 through the premature termination of translation. ${ }^{10}$ This suggests the applicability of an in vitro synthesised (IVS) protein assay in screening for DPC4 mutations. An advantage of the IVS assay is that it is adequately sensitive for analysis of native biopsy specimens. ${ }^{13}$ We have applied this assay successfully for the $A P C$ gene in colitis associated neoplasia. ${ }^{2} \mathrm{~K}$-ras mutations are also currently detectable by various sensitive assay methods, amounting to three genes the alterations of which could be detected in routine biopsy samples during surveillance for colitis associated neoplasia. We have now generated a genetic profile of colitis associated neoplasms including the mutation status of four genes (K-ras, p53, $A P C$, and DPC4). Aside from the potential in diagnostics, the understanding of the interplay of the multiple genetic aberrations in colitis associated neoplasms might also prove to be valuable in the understanding of the clinical progression of these neoplasms.

We thank the residents of the Department of Pathology for tissue collection, the surgeons and gastroenterologists of the
Johns Hopkins Hospital for their help in identification of Johns Hopkins Hospital for their help in identification of
patients and clinical information, and Dr Stanley R Hamilton patients and clinical information, and Dr Stanley $R$ Hamilton
and $\mathrm{Dr}$ John $\mathrm{H}$ Yardley for confirmation of dysplasias and aid and Dr John H Yardley for confirmation of dysplasias and aid
with tissue procurement. This work was supported by the NIH SPORE in Gastrointestinal Cancer, CA62924. SEK is a McDonnell Foundation Scholar.

1 Kern SE, Redston M, Caldas C, Seymour A, Kornacki S, Powell SM, et al. Molecular genetic profiles of colitisassociated neoplasms. Gastroenterology 1994; 107: 420-8.

2 Redston MS, Papadopoulos N, Caldas C, Kinzler KW, Redston MS, Papadopoulos N, Caldas C, Kinzler KW,
Kern SE. Common occurrence of $A P C$ and K-ras gene mutations in the spectrum of colitis-associated neoplasias. mutations in the spectrum of colitis-a

3 Burmer GC, Levine DS, Kulander BG, Haggitt RC, Rubin CE, Rabinovitch PS. c-Ki-ras mutations in chronic ulcerative colitis and sporadic colon carcinoma. Gastroenterology 1990; 99: 416-20.

4 Meltzer SJ, Mane SM, Wood PK, Resau JH, Newkirk C, Terzakis JA, et al. Activation of c-Ki-ras in human gastrointestinal dysplasias determined by direct sequencing of polymerase chain reaction products. Cancer Res 1990; 50: polymerase

5 Bell SM, Kelly SA, Hoyle JA, Lewis FA, Taylor GR, Thompson $\mathrm{H}$, et al. c-Ki-ras gene mutations in dysplasia and carcinomas complicating ulcerative colitis. $\mathrm{Br} f$ and carcinomas compl $1991 ; 64:$ 174-8.

6 Chen J, Compton C, Cheng E, Fromowitz F, Viola MV. c-Ki-ras mutations in dysplastic fields and cancers in ulcerative colitis. Gastroenterology 1992; 102: 1983-7.

7 Burmer GC, Rabinovitch PS, Haggitt RC, Crispin DA, Brentnall TA, Kolli VR, et al. Neoplastic progression in ulcerative colitis: histology, DNA content, and loss of a p53 allele. Gastroenterology 1992; 103: 1602-10.

8 Yin J, Harpaz N, Tong Y, Huang Y, Laurin J, Greenwald BD, et al. p53 point mutations in dysplastic and cancerous ulcerative colitis lesions. Gastroenterology 1993; 104: 1633-9.

9 Hahn SA, Seymour AB, Hoque ATMS, Schutte M, da Costa LT, Redston MS, et al. Allelotype of pancreatic adenocarcinoma using a xenograft model. Cancer Res 1995; 55: 4670-5.

10 Hahn SA, Schutte M, Hoque ATMS, Moskaluk CA, da Costa LT, Rozenblum E, et al. DPC4, a candidate tumorsuppressor gene at 18q21.1. Science 1996; 271: 350-3.

11 Fearon ER, Cho KR, Nigro JM, Kern SE, Simons JW, Ruppert JM, et al. Identification of a chromosome 18q gene that is altered in colorectal cancers. Science 1990; 247: 49-56.

12 Cairns P, Polascik TJ, Eby Y, Tokino K, Califano J, Merlo A, et al. Frequency of homozygous deletion at p16/CDKN2 in primary human tumors. Nature Genet 1995; 11: $210-2$.

13 Powell SM, Petersen GM, Krush AJ, Booker S, Jen J, Giardiello FM, et al. Molecular diagnosis of familial adenomatous polyposis. $N$ Engl $f$ Med 1993; 329: 1982-7. 